\title{
PENGARUH DISIPLIN KERJA, LINGKUNGAN KERJA DAN MOTIVASI KERJA TERHADAP KINERJA KARYAWAN PADA PT. HAZARA CIPTA PESONA
}

\author{
Nunu Nurjaya \\ Program Studi Manajemen, Fakultas Ekonomi dan Bisnis, Universitas Nasional, Jakarta \\ Email: nunu_nurjaya@civitas.unas.ac.id
}

\begin{abstract}
Abstrak
Kualitas Sumber Daya Manusia (SDM) merupakan salah satu faktor yang sangat penting untuk meningkatkan kinerja karyawan suatu perusahaan. Oleh karena itu diperlukan sumber daya manusia yang mempunyai kompetensi tinggi karena dapat mendukung peningkatan kinerja pegawai. Peneitian ini menggunakan metode kuaitatif dengan pendekatan analisis deskriptif. Data yang digunakan dalam penelitian ini adalah data cross section yang diperoleh dari sumber data primer. Pada penelitian ini yang menjadi populasi adalah seluruh karyawan PT. Hazara Cipta Pesona sebanyak 88 karyawan. Teknik sampling yang digunakan adalah sampling jenuh atau sensus. Analisis yang digunakan dalam penelitian ini adalah analisis inferensial dengan menggunakan regresi linear berganda. Dari penelitian ini, diketahui bahwa: (1) Variebel disiplin kerja berpengaruh positif dan signifikan terhadap kinerja karyawan PT. Hazara Cipta Pesona. (2) Variebel lingkungan kerja berpengaruh positif dan signifikan terhadap kinerja karyawan PT. Hazara Cipta Pesona; (3) Variebel motivasi kerja berpengaruh positif dan signifikan terhadap kinerja karyawan PT. Hazara Cipta Pesona.
\end{abstract}

Kata Kunci: Disiplin Kerja, Lingkungan Kerja, Motivasi Kerja, Kinerja Karyawan.

\begin{abstract}
Human Resources (HR) quality is one of the essential factors in improving a company's performance. Therefore we need human resources which have high competence because they can support the improvement of employee performance. This research uses a qualitative method with a descriptive analysis approach. The data used in this research is cross-section data obtained from primary data sources. In this study, the population is all employees of PT. Hazara Cipta Pesona as many as 88 employees. The sampling technique used is saturated sampling or census. The analysis used in this research is an inferential analysis using multiple linear regression. From this research, it is known that: (1) Work discipline variable has a positive and significant effect on the employee performance of PT. Hazara Cipta Pesona. (2) Work environment variables have a positive and significant impact on the performance of employees of PT. Hazara Cipta Pesona; (3) Work motivation variable has a positive and significant effect on employee performance at PT. Hazara Cipta Pesona.
\end{abstract}

Keywords: Work Discipline, Work Environment, Work Motivation, Employee Performance.

\section{A. PENDAHULUAN}

PT. Hazara Cipta Pesona salah satu perusahaan yang bergerak dibidang usaha event organizer, karena event organizer itulah perusahaan harus mengelola event tersebut dengan baik supaya event tersebut berjalan dengan lancar dan sesuai dengan permintaan klien. Supaya event-event besar terlaksana dengan baik tentunya perusahaan harus memiliki sumber 
daya manusia kinerja yang baik dan event tersebut melibatkan sdm yang banyak. Untuk menyelenggarakan event tersebut dalam pelaksanaan tugasnya agar fokus terhadap sasaran yang akan dicapai maka di buat Renstra yang terdiri dari Visi, Misi, Kebijakan dan Program untuk dilaksanakan dalam periode tertentu.

Untuk mendukung pelaksanaan tugas-tugas tersebut, organisasi telah menetapkan struktur organisasi perusahaan dengan memerinci secara hirarkhi posisi-posisi pada masingmasing organisasi perusahaan sesuai dengan peran, tugas dan fungsi masing-masing serta pola hubungan antar posisi-posisi dalam rangkaian kesatuan organisasi dan standar, prosedur kerja yang jelas.

Kinerja adalah hasil atau tingkat keberhasilan seseorang secara keseluruhan selama periode tertentu dalam melaksanakan tugas dibandingkan dengan berbagai kemungkinan, seperti standar hasil kerja, target atau sasaran atau kriteria yang telah ditentukan terlebih dahulu telah disepakati bersama (Rivai dan Basri, 2005:50)

PT. Hazara Cipta Pesona dalam upaya meningkatkan kualitas kinerja karyawan berusaha membenahi sistem kerja perusahaan dan kinerja karyawan yang ada dilingkungannya. Hal ini terlihat dari konsistensi perusahaan yang selalu melakukan evaluasi dan perubahan didalam organisasinya secara terus menerus. Salah satu upaya untuk meningkatkan kualitas kinerja karyawan adalah dengan melakukan pengukuran Indeks Kinerja Karyawan (IKK) sebagai tolok ukur untuk menilai tingkat kinerja karyawan.

\begin{tabular}{|c|c|c|c|l|}
\hline $\begin{array}{c}\text { Nilai } \\
\text { Persepsi }\end{array}$ & $\begin{array}{c}\text { Nilai interval } \\
\text { Kinerja }\end{array}$ & $\begin{array}{c}\text { Nilai Interval } \\
\text { Konversi IKK }\end{array}$ & Mutu Kinerja & Kinerja Karyawan \\
\hline 4 & $3,26-4,00$ & $81,26-100,00$ & A & SANGAT BAIK \\
3 & $2,51-3,25$ & $62,51-81,25$ & B & BAIK \\
2 & $1,76-2,50$ & $43,76-62,50$ & C & KURANG BAIK \\
1 & $1-1,75$ & $25,00-43,75$ & D & TIDAK BAIK \\
\hline
\end{tabular}

Sumber: PT. Hazara Cipta Pesona

Berikut ini adalah Rekapitulasi Hasil Indeks Kinerja Karyawan (IKK) PT. Hazara Cipta Pesona.

\begin{tabular}{|c|c|c|l|}
\hline Tahun & Nilai Interval & Mutu Kinerja & \multicolumn{1}{|c|}{ Kinerja Karyawan } \\
\hline 2016 & 3,29 & A & SANGAT BAIK \\
\hline 2017 & 3,11 & B & BAIK \\
\hline 2018 & 3,32 & A & SANGAT BAIK \\
\hline 2019 & 2,98 & B & BAIK \\
\hline 2020 & 2,72 & B & BAIK \\
\hline
\end{tabular}

Sumber: PT. Hazara Cipta Pesona

Dari tabel 2 diatas didapatkan gambaran mengenai hasil pengukuran Indeks Kinerja Karyawan PT. Hazara Cipta Pesona pada tahun 2016 mendapat nilai NIK = 3,29 dengan kategori Kinerja Karyawan "Sangat Baik". Tahun 2017 mendapat nilai NIK = 3,11 dengan kategori Kinerja Karyawan "Baik". Tahun 2018 mendapat nilai NIK = 3,32 dengan kategori Kinerja Karyawan "Sangat Baik". Tahun 2019 mendapat nilai NIK = 2,98 dengan kategori Kinerja Karyawan "Baik". Tahun 2020 mendapat nilai NIK = 2,72 dengan kategori Kinerja Karyawan "Baik". 
Jika di terjemahkan lagi lebih dalam bahwa hasil survei IKM rata - rata baik, baik disini juga terlihat naik turun dan memiliki tren menurun di tiga tahun terkahir, artinya mempunyai makna bahwa kinerja karyawan belum optimal dan terjadi permasalahan kinerja karyawan di PT. Hazara Cipta Pesona.

Berdasarkan informasi dan pengamatan langsung yang didapatkan peneliti dari Biro SDM di PT. Hazara Cipta Pesona tentang fenomena yang terjadi di lapangan, meski perusahaan telah memiliki dan menerapkan peraturan tentang kedisiplinan sesuai dengan peraturan kerja PT. Hazara Cipta Pesona tetapi masih ada karyawan yang melanggar seperti masih adanya karyawan yang sering datang terlambat, karyawan yang sering menunda pekerjaan sehingga tidak adanya efektifitas dalam pekerjaan yang menyebabkan pekerjaan tidak selesai tepat waktu, serta karyawan yang berada diluar kantor pada saat jam kerja berlangsung tanpa seizin pimpinan.

Disiplin kerja merupakan hal yang harus ditanamkan dalam diri tiap karyawan. Kesadaran karyawan diperlukan dengan mematuhi peraturan-peraturan yang berlaku. Peraturan sangat diperlukan untuk memberikan bimbingan dan penyuluhan bagi karyawan dalam menciptakan tata tertib yang baik di perusahaan. Selain itu perusahaan sendiri harus mengusahakan agar peraturan itu bersifat jelas, mudah dipahami dan berlaku bagi semua Pegawai (Hasibuan, 2008:194).

Lingkungan kerja di PT. Hazara Cipta Pesona juga merupakan salah satu faktor yang mempengaruhi kinerja karyawan. Masalah yang sering ditemukan yaitu adanya ketidak sesuaian antara karyawan yang satu dengan yang lain, dan hal tersebut mengakibatkan hubungan antar karyawan menjadi buruk dan menganggu proses sosialisasi dalam bekerja.

Selain itu sifat karyawan yang berperilaku negatif terhadap rekan kerja juga mempengaruhi kenyamanan dari karyawan lainya, maka menimbulkan lingkungan kerja yang tidak nyaman dalam bekerja, dan merasa untuk malas menyelesaikan tugas yang ada. Hal demikiam merupakan masalah yang sering terjadi dan mempengaruhi kinerja karyawan.

Selain disiplin kerja dan lingkungan kerja hal lain yang mempengaruhi kinerja yaitu Motivasi. Motivasi berasal dari kata Latin "movere" yang berarti dorongan atau menggerakkan. Motivasi mempersoalkan bagaimana cara mengarahkan daya dan potensi agar bekerja mencapai tujuan yang ditentukan (Hasibuan, 2006:141). Motivasi merupakan bentuk atau cara yang bisa dilakukan oleh para pimpinan untuk mendukung dan membimbing karyawannya untuk bisa menjadi lebih baik dari sebelumnya. Karyawan PT. Hazara Cipta Pesona sering merasa tidak bisa berkontribusi dengan baik, malas, merasa minder atau tidak bergairah untuk melaksanakan kewajibannya.

Berdasarkan latar belakang di atas, maka tujuan penelitian ini adalah untuk mengeuji pengaruh disiplin kerja, lingkungan kerja dan motivasi terhadap kinerja karyawan pada PT. Hazara Cipta Pesona.

\section{B. TINJAUAN PUSTAKA}

\section{Kinerja Karyawan}

Kinerja didefinisikan sebagai apa yang dilakukan atau tidak dilakukan pegawai. Kinerja pegawai adalah yang mempengaruhi seberapa banyak mereka memberi kontribusi terhadap perusahaan. Menurut Afandi (2018:83) Kinerja adalah hasil kerja yang dapat dicapai 
oleh seseorang atau kelompok orang dalam suatu perusahaan sesuai dengan wewenang dan tanggung jawab masing-masing dalam upaya pencapaian tujuan organisasi secara illegal, tidak melanggar hukum dan tidak bertentangan dengan moral dan etika.

Menurut Rivai (2012:309), kinerja merupakan perilaku nyata yang ditampilkan setiap orang sebagai prestasi kerja yang dihasilkan oleh pegawai sesuai dengan perannya dalam perusahaan. Menurut Simanjuntak (2010:1), kinerja adalah tingkat pencapaian hasil atas pelaksanaan tugas tertuntu.Kinerja perusahaan adalah tingkat pencapaian hasil dalam rangka mewujudkan tujuan perusahaan. Manajemen kinerja adalah keseluruhan kegiatan yang dilakukan untuk meningkatkan kinerja perusahaan atau organisasi, termasuk kinerja masingmasing individu dan kelompok kerja perusahaan tersebut.

Sementara menurut Wibowo (2010:4) Kinerja adalah implementasi dari rencana yang telah disusun tersebut. Implementasi kinerja dilakukan oleh sumber daya manusia yang memiliki kemampuan, kompetensi, motivasi, dan kepentingan. Bagaimana organisasi menghargai dan memperlakukan sumber daya manusianya akan memengaruhi sikap dan perilakunya dalam menjalankan kinerja.

Dari beberapa pendapat diatas maka dapat diketahui bahwa kinerja karyawan merupakan hasil kerja yang dicapai oleh seseorang karyawan sesuai dengan pekerjaan yang diberikan kepadanya dalam waktu tertentu. Tujuan melakukan penilaian kinerja karyawan oleh suatu perusahaan melakukan penilaian kinerja didasarkan pada dua alasan pokok, yaitu:

a. Manajer melakukan evaluasi yang objektif terhadap kinerja karyawan pada masa lalu yang digunakan untuk membuat keputusan di bidang SDM di masa yang akan datang.

b. Manajer memerlukan alat yang memungkinkan untuk membantu karyawannya memperbaiki kinerja, merencanakan pekerjaan, mengembangkan kemampuan dan keterampilan untuk perkembangan karier dan memperkuat kualitas hubungan antar manajer yang bersangkutan dengan karyawannya

Sementara menurut Afandi (2018:89), indikator-indikator kinerja pegawai adalah sebagai berikut :

a. Kuantitas hasil kerja

Segala macam bentuk satuan ukuran yang berhubungan dengan jumlah hasil kerja yang bisa dinyatakan dalam ukuran angka atau padanan angka lainnya.

b. Kualitas hasil kerja

Segala macam bentuk satuan ukuran yang berhubungan dengan kualitas atau mutu hasil kerja yang dapat dinyatakan dalam ukuran angka atau padanan angka lainnya.

c. Efesiensi dalam melaksanakan tugas

Berbagai sumber daya secara bijaksana dan dengan cara yang hemat biaya.

d. Disiplin kerja

Taat kepada hokum dan peraturan yang berlaku.

e. Inisiatif

Kemampuan untuk memutuskan dan melakukan sesuatu yang benar tanpa harus diberi tahu, mampu menemukan apa yang seharusnya dikerjakan terhadap sesuatu yang ada di sekitar, berusaha untuk terus bergerak untuk melakukan beberapa hal walau keadaan terasa semakin sulit. 
f. Ketelitian

Tingkat kesesuaian hasil pengukuran kerja apakah kerja itu udah mencapai tujuan apa belum.

g. Kepemimpinan

Proses mempengaruhi atau memberi contoh oleh pemimpin kepada pengikutnya dalam upaya mencapai tujuan organisasi.

h. Kejujuran

Salah satu sifat manusia yang cukup sulit untuk diterapkan.

i. Kreativitas

Proses mental yang melibatkan pemunculan gagasan atau yang melibatkan pemunculan gagasan.

\section{Disiplin Kerja}

Salah satu faktor yang sangat berpengaruh dalam sumber daya manusia adalah factor kedisiplinan. Disiplin merupakan salah satu funsi opertif manajemen sumber daya manusia. Menurut Siswanto (2013:291) menyatakan bahwasannya "disiplin kerja merupakan suatu sikap menghormati, menghargai, patuh dan taat terhadap peraturan-peraturan yang berlaku baik yang tertulis maupun yang tidak tertulis serta sanggup menjalankannya dan tidak mengelak menerima sanksisanksi apabila ia melanggar tugas dan wewenang yang diberikan kepadanya".

Menurut Hasibuan (2016:193) bahwa "kedisiplinan adalah kesadaran dan kerelaan seseorang dalam menaati semua peraturan perusahaan dan norma-norma sosial yang berlaku". Menurut Sutrisno (2016:89) mengatakan bahwa "disiplin karyawan adalah perilaku seorang dengan peraturan, prosedur kerja yang ada atau disiplin adala sikap, tingkah laku, dan perbuatan yang sesuai dengan peraturan dari organisasi baik tertulis maupun yang tidak tertulis". Menurut Rivai (2011:825) menyatakan bahwa "Disiplin kerja adalah suatu alat yang dipergunakan para manajer untuk berkomunikasi dengan pegawai agar mereka bersedia untuk mengubah suatu perilaku serta sebagai suatu upaya untuk meningkatkan kesadaran dan kesediaan seorang dalam memenuhi segala peraturan perusahaan”.

Sedangkan menurut Handoko (2014:208), “disiplin adalah kegiatan manajemen untuk menjalankan standar-standar organisasional. Dari pendapat ini standar peraturan perusahaan akan ternilai dengan tingkat disipin karyawan, apakah karyawan sudah menjalankan standard dan prosedur yang berlaku atau tidak, serta ke efektifan standar perusahaan dalam menindaklanjuti hasil temuan disiplin kerja karyawan".

Singodimedjo dalam Edy Sutrisno (2016:89) mengemukakan faktor-faktor yang mempengaruhi disiplin kerja adalah:

a. Besar kecilnya pemberian kompensasi.

Para karyawan akan mematuhi segala peraturan yang berlaku, bila ia merasa mendapat jaminan balas jasa yang setimpal dengan jerih payahnya yang telah dikontribusikan bagi perusahaan.

b. Ada tidaknya keteladanan pimpinan dalam perusahaan.

Keteladanan pimpinan sangat penting sekali karena dalam lingkungan perusahaan, semua karyawan akan selalu memperhatikan bagaimana pimpinan dapat menegakkan 
disiplin dirinya dan bagaimana ia dapat menggendalikan dirinya dari ucapkan, perbuatan, dan sikap yang dapat merugikan aturan disiplin yang telah ditetapkan.

c. Ada tidaknya aturan pasti yang dapat dijadikan pegangan.

Pembinaan disiplin tidak akan dapat terlaksana dalam perusahaan, bila tidak ada aturan tertulis yang pasti untuk dapat dijadikan pegangan bersama.

d. Keberanian pimpinan dalam mengambil tindakan.

Dengan adanya tindakan terhadap pelanggaran disiplin, sesuai dengan sangsi yang ada, maka semua karyawan akan merasa terlindungi, dan dalam hatinya berjanji tidak akan berbuat hal yang serupa.

e. Ada tidaknya pengawasan pemimpin.

Dalam setiap kegiatan yang dilakukan oleh perusahaan perlu ada pengawasan, yang akan mengarahkan karyawan agar dapat melaksanakan pekerjaan dengan tepat dan sesuai dengan yang telah ditetapkan.

f. Ada tidaknya perhatian kepada para karyawan.

Karyawan adalah manusia yang mempunyai perbedaan karakter antara satu dengan yang lain. Seorang karyawan tidak hanya puas dengan penerimaan kompensasi yang tinggi, pekerjaan yang menantang, tetapi juga mereka masih membutuhkan perhatian yang besar dari pimpinannya sendiri.

g. Diciptakan kebiasaan-kebiasaan yang mendukung tegaknya disiplin.

Kebiasaan-kebiasaan positif itu antara lain:

a. Saling menghormati, bila bertemu di lingkungan pekerjaan.

b. Melontarkan pujian sesuai dengan tempat dan waktunya, sehingga para karyawan akan turut merasa bangga dengan pujian tersebut.

c. Sering mengikutsertakan karyawan dalam pertemuan-pertemuan, apalagi pertemuan yang berkaitan dengan nasib dan pekerjaan mereka.

d. Memberi tahu bila ingin meninggalkan tempat kepeda rekan kerja, dengan menginformasikan, ke mana dan untuk urusan apa, walaupun kepada bawahan sekalipun.

Bejo Siswanto dalam Lijan Poltak Sinambela (2016:356) memaparkan dimensi dan indikator dalam kedisiplinan yaitu:

a. Frekuensi kehadiran

Frekuensi kehadiran merupakan salah satu tolak ukur untuk mengetahui tingkat kedisiplinan karyawan. Semakin tinggi frekuensi kehadirannya maka karyawan tersebut telah memiliki disiplin kerja yang tinggi. Berikut indikator frekuensi kehadiran diukur dengan menggunkan dua indikator yaitu: Kehadiran karyawan tepat waktu di tempat kerja, dan absensi.

b. Tingkat kewaspadaan karyawan

Karyawan yang dalam pelaksanaan pekerjaanya selalu penuh perhitungan dan ketelitian memiliki tingkat kewaspadaan yang tinggi terhadap dirinya maupun pekerjaanya. Berikut indikator tingkat kewaspadaan karyawan diukur dengan menggunakan dua indikator yaitu: Ketelitian, dan Perhitungan. 
c. Ketaatan pada standar kerja

Dalam melaksanakan pekerjaanya karyawan diharuskan menatati semua standar kerja yang telah ditetapkan sesuai dengan aturan-aturan dan pedoman kerja agar kecelakaan kerja tidak terjadi atau dapat dihindari. Berikut indikator dimensi ketaatan pada standar kerja diukur dengan menggunkan indikator yaitu: Menatati peraturan dan pedoman kerja, dan Tanggung jawab.

d. Ketaatan pada peraturan kerja

Dimaksudkan demi kenyamanan dan kelancaran dalam bekerja. Dimensi ketaatan pada peraturan kerja diukur dengan dua indikator yaitu: Kepatuhan, dan Kelancaran.

e. Etika kerja

Diperlukan oleh setiap karyawan dalam melaksanakan pekerjaanya agar tercipta suasana harmonis, saling menghargai antar sesama karyawan. Dimensi etika kerja diukur dengan menggunkan indikator yaitu: Suasana harmonis, dan Saling menghargai.

\section{Lingkungan Kerja}

Lingkungan kerja merupakan salah satu faktor penting dalam menciptakan kinerja pegawai. Karena lingkungan kerja mempunyai pengaruh langsung terhadap pegawai didalam menyelesaikan pekerjaan yang pada akhirnya akan meningkatkan kinerja organisasi. Suatu kondisi lingkungan kerja dikatakan baik apabila pegawai dapat melaksanakan kegiatan secara optimal, sehat, aman, dan nyaman.

Menurut Afandi (2018:65) lingkungan kerja adalah segala sesuatu yang ada disekitar karyawan dan dapat mempengaruhi dalam menjalankan tugas yang diembankan kepadanya misalnya dengan adanya air conditioner (AC), penerangan yang memadai sebagainya.

Menurut Sedarmayanti dalam Susanti (2015:9) tentang definisi lingkungan kerja adalah keseluruhan alat perkakas dan bahan yang dihadapi, lingkungan sekitarnya dimana seseorang bekerja, metode kerjanya, serta pengaturan kerjanya baik sebagai perseorangan maupun sebagai kelompok.

Menurut Mardiana dalam Sanny dan Kristanti (2012:11), lingkungan kerja adalah lingkungan dimana pegawai melakukan pekerjaannya sehari-hari. Jika pegawai menyenangi lingkungan kerja dimana dia bekerja, maka pegawai tersebut akan betah di tempat kerjanya untuk melakukan aktivitas sehingga waktu kerja dipergunakan secara efektif dan optimis prestasi kerja pegawai juga tinggi. Lingkungan kerja tersebut mencakup hubungan kerja yang terbentuk antara sesama pegawai dan hubungan kerja antar bawahan dan atasan serta lingkungan fisik tempat pegawai bekerja.

Afandi (2018:66) menyatakan untuk menciptakan lingkugan kerja yang baik ada beberapa hal yang harus diperhatikan yaitu:
a. Bangunan tempat kerja
b. Ruang kerja yang lapang
c. Ventilasi udara yang baik
d. Tersedianya tempat ibadah
e. Tersedianya sarana angkutan pegawai 
Menurut Afandi (2018:71) menyebutkan beberapa indikator lingkungan kerja yaitu sebagai berikut:
a. Lampu penerangan tempat kerja
b. Jendela tempat kerja
c. Tata warna
d. Dekorasi
e. Bunyi musik
f. Suhu udara
g. Kelembaban udara

\section{Motivasi Kerja}

Motivasi sebagai upaya yang dapat memberikan dorongan kepada seseorang untuk mengambil suatu tindakan yang dikehendaki, sedangkan motif sebagai daya gerak seseorang untuk berbuat, karena perilaku seseorang cenderung berorientasi pada tujuan dan didorong oleh keinginan untuk mencapai tujuan tertentu. Beberapa pengertian motivasi menurut ahli yaitu :

Menurut Hasibuan (2016:111) mengemukakan "motivasi adalah pemberian daya penggerak yang menciptakan kegairahan kerja seseorang, agar mereka mau bekarja sama, bekerja efektif, dan terintegrasi dengan segala daya upayanya untuk mencapai kepuasan". Menurut Mangkunegara (2013:94) bahwa "motivasi merupakan Kondisi jiwa yang mendorong seseorang dalam mencapai prestasinya secara maksimal". Menurut Wilson Bangun (2012:312) "motivasi didefinisikan sebagai suatu tindakan untuk mempengaruhi orang lain agar berperilaku (to behave) secara teratur".

Menurut Samsudin (2010: 281) mengemukakan bahwa "motivasi adalah proses mempengaruhi atau mendorong dari luar terhadap seseorang atau kelompok kerja agar mereka mau melaksanakan sesuatu yang telah ditetapkan". Menurut Siagian (2012:138) memberikan pengertian "motivasi adalah daya pendorong yang mengakibatan seseorang anggota organisasi mau/rela untuk mengerahkan kemampuan, dalam bentuk keahlian dan keterampilan, tenaga dan waktunya untuk menyelenggarakan berbagai kegiatan yang menjadi tanggung jawabnya dan menunaikan kewajibannya, dalam rangka pencapaian tujuan dan berbagai sasaran organisasi yang telah ditentukan sebelumnya”.

Menurut Afandi (2018:23) motivasi adalah keinginan yang timbul dari dalam diri seseorang atau individual karena terinspirasi, tersemangati, dan terdorong untuk melakukan aktifitas dengan keikhlasan, senang hati dan sungguh-sungguh sehingga hasil dari aktifitas yang dilakukan mendapat hasil yang baik dan berkualitas. Sedangkan menurut Sutrisno (2011: 109) Motivasi adalah suatu faktor yang mendorong seseorang untuk melakukan suatu aktifitas tertentu, oleh karena itu motivasi sering kali diartikan pula sebagai faktor pendorong perilaku seseorang.

Ada dua jenis motivasi, yaitu motivasi positif dan motivasi negative menurut Hasibuan (2010:150), yaitu:

a. Motivasi Positif (Insentif Positif).

Motivasi positif maksudnya manajer memotivasi (merangsang) bawahan dengan memberikan hadiah kepada mereka yang berprestasi di atas prestasi standar. Dengan 
motivasi positif, semangat kerja bawahan akan meningkat karena pada umumnya manusia senang menerima yang baik-baik.

b. Motivasi negatif (Insentif Negatif).

Motivasi negatif maksudnya manajer memotivasi bawahan dengan standar mereka akan mendapat hukuman. Dengan motivasi negatif ini semangat kerja pegawai dalam jangka waktu pendek akan meningkat karena mereka takut dihukum, tetapi dalam jangka waktu yang panjang dapat berakibat kurang baik.

Menurut Afandi (2018:29) menyebutkan beberapa indikator dari motivasi yaitu sebagai berikut:

a. Balas jasa

Segala sesuatu yang berbentuk barang, jasa, dan uang yang merupakan kompensasi yang diterima pegawai karena jasanya yang dilibatkan pada organisasi.

b. Kondisi kerja

Kondisi atau keadaan lingkungan kerja dari suatu perusahaan yang menjadi tempat bekerja dari para pegawai yang bekerja disalam lingkungan tersebut. Kondisi kerja yang baik yaitu nyaman dan mendukung pekerja untuk dapat menjalankan aktivitasnya dengan baik.

c. Fasilitas kerja

Segala sesuatu yang terdapat dalam organisasi yang ditempati dan dinikmati oleh pegawai, baik dalam hubungan langsung dengan pekerjaan maupun untuk kelancaran pekerjaan.

d. Prestasi kerja

Hasil yang dicapai atau yang diinginkan oleh semua orang dalam bekerja. Untuk tiaptiap orang tidaklah sama ukuranya karena manusia itu satu sama lain berbeda.

e. Pengakuan dari atasan

Pernyataan yang diberikan dari atasan apakah pegawainya sudah menerapkan akan motivasi yang telah diberikan atau tidak.

f. Pekerjaan itu sendiri

Pegawai yang mengerjakan pekerjaan dengan sendiri apakah pekerjaannya bisa menjadi motivasi buat pegawai lainnya.

\section{Pengaruh Disiplin Kerja Terhadap Kinerja Karyawan}

Kinerja kerja erat kaitannya dengan kedisiplinan karena akan terukur kinerja sumber daya manusia pada sebuah organisasi atau perusahaan ketika kedisiplinannya sudah terkontrol dengan baik oleh manajemen sumber daya manusia. Oleh karenanya kedisiplinan tidak dapat dilupakan dalam penilaian kinerja dalam sebuah perusahaan atau organisasi sebab kedisiplinan berpengaruh positif terhadap kinerja karyawan.

Penelitian-penelitan sebelumnya pun menyatakan bahwa kedisiplinan karyawan memengaruhi terhadap kinerja kerja karyawan seperti hasil dari penelitian yang dilakukan oleh Dina Rahmayanti, pada tahun 2014 menyatakan 49 bahwa kedisiplinan berpengaruh signifikan terhadap kinerja kerja karyawan dari hasil pengolahan data yang ia lakukan. Senada dengan hasil penelitian yang dilakukan oleh Dina Rahmayanti, Faradistia R. Paputungan pada tahun 2013 menyatakan bahwa dari beberapa variabel yang ia teliti, 
kedisiplinan merupakan variabel yang berpengaruh besar terhadap kinerja kerja karyawan pada tempat penelitiannya

H1 : Disiplin Kerja berpengaruh Positif dan Signifikan terhadap Kinerja

Karyawan Pada PT. Hazara Cipta Pesona.

\section{Pengaruh Lingkungan Kerja Terhadap Kinerja Karyawan}

Kondisi karyawan sangat bergantung pada bagaimana keadaan dalam perusahaan tempat ia bekerja. Hal ini dapat dipengaruhi langsung oleh lingkungan fisik dan juga lingkungan non fisik. Perusahaan harus bisa membuat bagaimana cara agar karyawan merasa nyaman dengan lingkungan yang diberikan oleh perusahaan. Bila perusahaan gagal menciptakan lingkungan yang kondusif, hal ini akan sangat mengganggu konsentrasi kerja karyawan, sehingga berdampak pada menurunnya tingkat kinerja karyawan itu sendiri.

Menurut Wibowo (2014), bahwa lingkungan kerja atau situasi kerja memberikan kenyamanan akan mendorong kinerja karyawan. Termasuk bagaimana kondisi hubungan antar manusia di dalam organisasi, baik antara atasan dengan bawahan maupun diantara rekan sekerja. Faktor-faktor tersebut merupakan faktor lingkungan internal organisasi.

H2 : Lingkungan Kerja berpengaruh Positif dan Signifikan terhadap Kinerja Karyawan Pada PT. Hazara Cipta Pesona.

\section{Pengaruh Motivasi Kerja Individu Terhadap Kinerja Karyawan}

Motivasi merupakan unsur penting dalam diri manusia yang berperan dalam mewujudkan keberhasilan dalam usaha maupun pekerjaan manusia. Hal ini sependapat dengan Teori X dan Teori Y Mc. Gregor. Menurut teori X untuk memotivasi pegawai harus dilakukan dengan cara pengawasan yang ketat, dipaksa, dan diarahkan supaya mau bekerja sungguh-sungguh. Jenis motivasi yang diterapkan cenderung motivasi negatif yakni dengan menerapkan hukuman yang tegas. Sedangkan menurut teori Y, untuk memotivasi pegawai dilakukan dengan cara peningkatan partisipasi, kerjasama, dan keterikatan pada keputusan. Dengan adanya motivasi pegawai akan dapat meningkatkan kinerja mereka (Hasibuan, 2010:152-167).

Motivasi diperlukan oleh karyawan agar tergerak untuk melakukan suatu aktivitas kerja. Pemberian motivasi oleh pimpinan dan perusahan adalah sangat penting, karena motivasi sangat berperan dalam membangun semangat kerja karyawan. David C. Mc Clelland dalam Mangkunegara (2013:68) berpendapat bahwa ada hubungan yang positif antara motif berprestasi dengan pencapaian kinerja.

Menurut Umi Rusilowati dan, Fifth Ernawat (2018) dengan judul Pengaruh Gaya Kepemimpinan, Motivasi, Dan Kepuasan Kerja Terhadap Kinerja Karyawan (Pada Badan Penelitian Dan Pengembangan" Hasil penelitian menunjukkan Gaya Kepemimpinan (X1) berpengaruh positif dan signifikan terhadap Kinerja (Y) pegawai Balitbang Kemendagri. Motivasi (X2) berpengaruh positif dan signifikan terhadap Kinerja (Y) pegawai balitbang Kemendagri.Kepuasan kerja (X3) berpengaruh positif dan signifikan terhadap Kinerja (Y) pegawai Balitbang Kemendagri. Gaya kepemimpinan (X1), Motivasi (X2) dan Kepuasan Kerja (X3) berpengaruh positif dan signifikan secara bersama-sama terhadap Kinerja (Y) pegawai Balitbang Kemendagri. 
H3 : Motivasi Kerja berpengaruh Positif dan Signifikan terhadap Kinerja

Karyawan Pada PT. Hazara Cipta Pesona.

\section{METODE}

Pendekatan penelitian yang digunakan dalam penelitian ini adalah pendekatan kuantitatif. Data yang digunakan dalam penelitian ini adalah data cross section yang diperoleh dari sumber data primer, yakni dari penyebaran kuesioner kepada sampel (responden) yang telah ditentukan. Pada penelitian ini yang menjadi populasi adalah seluruh karyawan PT. Hazara Cipta Pesona sebanyak 88 karyawan. Teknik sampling yang digunakan adalah sampling jenuh atau sensus, sehingga jumlah responden adalah sejumlah dengan populasi yang ada yaitu sebanyak 88 karyawan.

Analisis yang digunakan dalam penelitian ini adalah analisis inferensial dengan menggunakan regresi linear berganda untuk menganalisis pengaruh disiplin kerja, lingkungan kerja dan motivasi kerja karyawan PT. Hazara Cipta Pesona.

\section{HASIL DAN PEMBAHASAN}

Pengujian instrumen penelitian ini diuji dengan menggunakan uji validitas dan reliabilitas. Hasil uji validitas menunjukkan bahwa instrumen penelitian ini semuannya valid karena memiliki rhitung yang lebih besar daripada rtabel-nya. Adapun hasil uji reliabilitas menunjukkan bahwa instrumen dari setiap variabel yang digunakan dalam penelitian ini reliabel karena memiliki nilai cronbach alpha yang lebih besar dari 0,7.

Sementara itu, hasil uji asumsi klasik menunjukkan bahwa data penelitian terdistribusi normal, serta terbebas dari multikolinearitas, heteroskedastisitas dan autokorelasi. Pengujian regresi linear berganda bertujuan untuk mengetahui ada tidaknya pengaruh variabel independen (disiplin kerja, lingkungan kerja, dan motivasi kerja) terhadap variabel dependen (kinerja karyawan) pada PT. Hazara Cipta Pesona.

Perhitungan statistik dalam analisis regresi linear berganda menggunakan SPSS Versi 23.0. Berdasarkan hasil analisis regresi linear berganda diperoleh hasil sebagai berikut:

Coefficients $^{a}$

\begin{tabular}{|c|c|c|c|c|c|c|c|c|}
\hline \multirow{2}{*}{\multicolumn{2}{|c|}{ Model }} & \multicolumn{2}{|c|}{$\begin{array}{c}\text { Unstandardized } \\
\text { Coefficients }\end{array}$} & \multirow{2}{*}{$\begin{array}{c}\text { Standardized } \\
\text { Coefficients } \\
\text { Beta }\end{array}$} & & \multirow[b]{2}{*}{ Sig. } & \multicolumn{2}{|c|}{ Collinearity Statistics } \\
\hline & & $\mathrm{B}$ & Std. Error & & & & Tolerance & VIF \\
\hline \multirow[t]{4}{*}{1} & (Constant) & 1.263 & 1.209 & & 1.045 & .299 & & \\
\hline & Disiplin Kerja & .407 & .073 & .430 & 5.554 & .000 & .717 & 1.395 \\
\hline & Lingkungan Kerja & .252 & .071 & .268 & 3.557 & .001 & .757 & 1.321 \\
\hline & Motivasi Kerja & .248 & .080 & .263 & 3.111 & .002 & .603 & 1.658 \\
\hline
\end{tabular}

a. Dependent Variable: Kinerja Karyawan

Berdasarkan hasil perhitungan di atas diperoleh persamaan regresi linear berganda dari variabel dari variabel Disiplin Kerja $\left(\mathrm{X}_{1}\right)$, Lingkungan Kerja $\left(\mathrm{X}_{2}\right)$, dan Motivasi Kerja $\left(\mathrm{X}_{3}\right)$ terhadap Kinerja Karyawan (Y) adalah sebagai berikut: $\mathrm{Y}=\mathbf{1 , 2 6 3}+\mathbf{0 , 4 0 7} \mathrm{X}_{1}+\mathbf{0 , 2 5 2} \mathrm{X}_{\mathbf{2}}+$ 0,248 X3.

Keterangan:

$$
\begin{array}{ll}
\mathrm{Y}^{\prime} & =\text { Kinerja Karyawan yang diprediksi } \\
\mathrm{a} & =\text { konstanta }
\end{array}
$$




$\begin{array}{ll}\mathrm{b} 1, \mathrm{~b} 2, \mathrm{~b} 3 & =\text { koefisien regresi } \\ \mathrm{X}_{1} & =\text { Disiplin Kerja } \\ \mathrm{X}_{2} & =\text { Lingkungan Kerja } \\ \mathrm{X}_{3} & =\text { Motivasi Kerja }\end{array}$

Persamaan regresi di atas memiliki dapat dijelaskan sebagai berikut :

a. Konstanta sebesar 1,263; artinya jika Disiplin Kerja $\left(\mathrm{X}_{1}\right)$, Lingkungan Kerja $\left(\mathrm{X}_{2}\right)$ dan Motivasi Kerja $\left(\mathrm{X}_{3}\right)$ nilainya adalah 0, maka Kinerja Karyawan (Y') nilainya adalah 1,263

b. Koefisien regresi variabel Disiplin Kerja $\left(\mathrm{X}_{1}\right)$ sebesar 0,407 ; artinya jika variabel independen lain nilainya tetap dan Disiplin Kerja mengalami kenaikan 1\%, maka Kinerja Karyawan (Y') akan mengalami peningkatan sebesar 0,407. Koefisien bernilai positif artinya terjadi hubungan positif antara Disiplin Kerja dengan Kinerja Karyawan, sehingga semakin baik Disiplin Kerja maka semakin meningkat Kinerja Karyawan.

c. Koefisien regresi variabel Lingkungan Kerja $\left(\mathrm{X}_{2}\right)$ sebesar 0,252; artinya jika variabel independen lain nilainya tetap dan Lingkungan Kerja mengalami kenaikan 1\%, maka Kinerja Karyawan (Y') akan mengalami peningkatan sebesar 0,252. Koefisien bernilai positif artinya terjadi hubungan positif antara Lingkungan Kerja dengan Kinerja Karyawan, sehingga semakin baik Disiplin Kerja maka semakin meningkat Kinerja Karyawan.

d. Koefisien regresi variabel Motivasi Kerja $\left(\mathrm{X}_{3}\right)$ sebesar 0,248; artinya jika variabel independen lain nilainya tetap dan Motivasi Kerja mengalami kenaikan 1\%, maka Kinerja Karyawan (Y') akan mengalami peningkatan sebesar 0,248. Koefisien bernilai positif artinya terjadi hubungan positif antara Motivasi Kerja dengan Kinerja Karyawan, sehingga semakin baik Motivasi Kerja maka semakin meningkat Kinerja Karyawan.

\begin{tabular}{l|c|r|r|r|c|}
\hline & Model Summary \\
Model & $\mathrm{R}$ & $\mathrm{R}$ Square & $\begin{array}{c}\text { Adjusted } \\
\text { R Square }\end{array}$ & $\begin{array}{c}\text { Std. Error of the } \\
\text { Estimate }\end{array}$ & $\begin{array}{c}\text { Durbin- } \\
\text { Watson }\end{array}$ \\
\hline 1 & $.766^{\text {a }}$ & .587 & .574 & 1.3266 & 2.214 \\
\hline
\end{tabular}
a. Predictors: (Constant), Motivasi Kerja, Lingkungan Kerja, Disiplin Kerja
b. Dependent Variable: Kinerja Karyawan

Berdasarkan hasil perhitungan di atas diperoleh nilai koefisien korelasi (R) sebesar 0,766 atau 76,6\% yang berarti tingkat hubungan antar variabel disiplin kerja $\left(\mathrm{X}_{1}\right)$, lingkungan kerja $\left(\mathrm{X}_{2}\right)$, dan motivasi kerja $\left(\mathrm{X}_{3}\right)$ terhadap kinerja karyawan $(\mathrm{Y})$ pada PT. Hazara Cipta Pesona memiliki tingkat hubungan yang kuat. Serta nilai koefisien determinasi $\left(\mathrm{R}^{2}\right)$ sebesar 0,587 yang artinya bahwa faktor disiplin kerja $\left(\mathrm{X}_{1}\right)$, lingkungan kerja $\left(\mathrm{X}_{2}\right)$, dan motivasi kerja $\left(\mathrm{X}_{3}\right)$ terhadap kinerja karyawan (Y) pada PT. Hazara Cipta Pesona 58,7\% dan sisanya 41,3\% dapat dijelaskan oleh faktor-faktor lain yang tidak diteliti dalam penelitian ini

Uji Secara Parsial (Uji t) yaitu untuk mengetahui signifikansi pengaruh variabel disiplin kerja $\left(\mathrm{X}_{1}\right)$, lingkungan kerja $\left(\mathrm{X}_{2}\right)$, dan motivasi kerja $\left(\mathrm{X}_{3}\right)$ terhadap kinerja karyawan (Y) pada PT. Hazara Cipta Pesona secara parsial atau individu menerangkan variabel 
dependen (kinerja karyawan). Pengujian data dalam penelitian ini menggunakan aplikasi SPSS 23.0 dengan hasil sebagai berikut:

Coefficients $^{\mathrm{a}}$

\begin{tabular}{|c|c|c|c|c|c|c|}
\hline \multirow[b]{2}{*}{ Model } & & \multicolumn{2}{|c|}{$\begin{array}{l}\text { Unstandardized } \\
\text { Coefficients }\end{array}$} & \multirow{2}{*}{$\begin{array}{c}\begin{array}{c}\text { Standardized } \\
\text { Coefficients }\end{array} \\
\text { Beta }\end{array}$} & \multirow[b]{2}{*}{$\mathrm{t}$} & \multirow[b]{2}{*}{ Sig. } \\
\hline & & $B$ & Std. Error & & & \\
\hline \multirow[t]{4}{*}{1} & (Constant) & 1.263 & 1.209 & & 1.045 & .299 \\
\hline & Disiplin Kerja & .407 & .073 & .430 & 5.554 & .000 \\
\hline & Lingkungan Kerja & .252 & .071 & .268 & 3.557 & .001 \\
\hline & Motivasi Kerja & .248 & .080 & .263 & 3.111 & .002 \\
\hline
\end{tabular}

a. Dependent Variable: Kinerja Karyawan

Hasil uji hipotesis dari penelitian ini disajikan dalam tabel sebagai berikut:

\begin{tabular}{|l|c|c|l|}
\hline \multicolumn{1}{|c|}{ Variabel Independen } & t-hitung & Signifikansi & \multicolumn{1}{c|}{ Keterangan } \\
\hline Disiplin Kerja & 5,554 & 0,000 & Positif dan Signifikan \\
\hline Lingkungan Kerja & 3,557 & 0,001 & Positif dan Signifikan \\
\hline Motivasi Kerja & 3,111 & 0,002 & Positif dan Signifikan \\
\hline
\end{tabular}

Sumber: Olah Data (2021)

Berdasarkan tabel di atas, setiap variabel independen dalam penelitian ini, yaitu disiplin kerja $\left(\mathrm{X}_{1}\right)$, lingkungan kerja $\left(\mathrm{X}_{2}\right)$, dan motivasi kerja $\left(\mathrm{X}_{3}\right)$ secara parsial berpengaruh positif dan signifikan terhadap kinerja karyawan (Y) pada PT. Hazara Cipta Pesona.

Hipotesis Secara Simultan (Uji F) digunakan untuk mengetahui apakah variabel independen disiplin kerja $\left(\mathrm{X}_{1}\right)$, lingkungan kerja $\left(\mathrm{X}_{2}\right)$, dan motivasi kerja $\left(\mathrm{X}_{3}\right)$ secara simultan atau bersama-sama mempengaruhi variabel dependen kinerja karyawan (Y) pada pada PT. Hazara Cipta Pesona. Pengujian ini menggunakan aplikasi SPSS 23.0 dengan hasil sebagai berikut:

\section{ANOVA $^{\mathrm{a}}$}

\begin{tabular}{|ll|r|r|r|r|r|}
\hline Model & & Sum of Squares & \multicolumn{1}{c|}{$\mathrm{df}$} & Mean Square & $\mathrm{F}$ & Sig. \\
\hline 1 & Regression & 239.806 & 3 & 79.935 & 45.422 & $.000^{\text {D }}$ \\
& Residual & 168.944 & 96 & 1.760 & & \\
& Total & 408.750 & 99 & & & \\
& & & & & \\
\hline
\end{tabular}

a. Dependent Variable: Kinerja Karyawan

b. Predictors: (Constant), Motivasi Kerja, Lingkungan Kerja, Disiplin Kerja

Berdasarkan perhitungan $F_{\text {hitung }}$ pada tabel di atas diperoleh hasil sebesar 45,422 sedangkan $F_{\text {tabel }}$ sebesar 0,1169. Jika dibandingkan dengan nilai $F_{\text {tabel }}$ maka dapa dilihat bahwa $(11,541>0,1169)$ dan nilai signifikansi sebesar 0,000 yang lebih kecil daripada 0,05, sehingga model penelitian ini terbukti layak karena disiplin kerja $\left(\mathrm{X}_{1}\right)$, lingkungan kerja $\left(\mathrm{X}_{2}\right)$, dan motivasi kerja $\left(\mathrm{X}_{3}\right)$ secara simultan berpengaruh positif dan signifikan terhadap kinerja karyawan (Y).

Hasil penelitian ini menunjukkan bahwa disiplin kerja berpengaruh positif dan signifikan terhadap kinerja karyawan PT. Hazara Cipta Pesona. Hal tersebut membuktikan bahwa semakin baik disiplin kerja yang diterapkan di PT. Hazara Cipta Pesona, maka semakin baik pula kinerja karyawan. Begitupun sebaliknya. Hal tersebut sejalan dengan temuan Purnomo Budi Setiyawan dan Waridin (2006) tentang "Pengaruh Disiplin Kerja terhadap Kinerja di Divisi Radiologi RSUP Dokter Kariadi Semarang”, disimpulkan bahwa positif dan signifikan disiplin kerja terhadap kinerja karyawan. 
Karena disiplin kerja memiliki pengaruh yang positif dan signifikan terhadap kinerja karyawan, maka aturan perusahaan tentang disipilin dalam bekerja harus diberlakukan bagi seluruh karywan PT. Hazara Cipta Pesona agar semua karyawan melakukan pekerjaan yang menjadi tugas dan tanggung jawabnya sesuai dengan apa yang diharapkan oleh perusahaan.

Hasil penelitian ini menunjukkan bahwa lingkungan kerja berpengaruh positif dan signifikan terhadap kinerja karyawan PT. Hazara Cipta Pesona. Hal tersebut membuktikan bahwa semakin baik lingkungan kerja yang diterapkan di PT. Hazara Cipta Pesona, maka semakin baik pula kinerja karyawan. Begitupun sebaliknya. Hal tersebut sejalan dengan temuan Ririn Prihatin (2011) yang berjudul "Pengaruh Kompensasi dan Lingkungan Kerja terhadap Kinerja Karyawan (Studi Kasus pada Perusahaan Manufaktur PT Borneo Melintang Buana Eksport)" Hasil penelitan menunjukan bahwa terdapat pengaruh positif dan signifikan lingkungan kerja terhadap kinerja karyawan pada PT. Borneo.

Karena lingkungan kerja memiliki pengaruh yang positif dan signifikan terhadap kinerja karyawan maka kondisi lingkungan kerja harus sesuai dengan diri karyawan agar tidak merasa terganggu ketika mereka bekerja, sehingga dengan kenyamanan tersebut mereka terpacu dalam bekerja, hal ini menyebabkan banyak pekerjaan dapat terselesaikan dengan baik sehingga dapat meningkatkan kinerja karyawan.

Hasil penelitian ini menunjukkan bahwa motivasi kerja berpengaruh positif dan signifikan terhadap kinerja karyawan PT. Hazara Cipta Pesona. Hal tersebut membuktikan bahwa semakin baik motivasi kerja yang diterapkan di PT. Hazara Cipta Pesona, maka semakin baik pula kinerja karyawan. Begitupun sebaliknya. Hal tersebut sejalan dengan temuan Yadi (2012) dengan judul "Pengaruh Motivasi terhadap Kinerja Karyawan pada CV. Dharma Utama Kota Baru. Hasil penelitan menunjukan bahwa terdapat pengaruh positif dan signifikan motivasi kerja terhadap terhadap kinerja karyawan.

Karena motivasi kerja berpengaruh positif dan singifikan terhadap kinerja karyawan. maka kurangnya pemberian motivasi kerja bisa menimbulkan masalah seperti kinerja karyawan yang rendah. Mangkunegara (2005:67), menyatakan faktor yang mempengaruhi kinerja adalah faktor kemampuan dan faktor motivasi, dalam hal ini perusahaan harus semakin kuat memberikan dorongan atau motivasi dan semangat maka akan semakin tinggi kinerjanya karyawan.

\section{E. KESIMPULAN}

Berdasarkan hasil penelitian ini, dapat disimpulkan bahwa disiplin kerja, lingkungan kerja, dan motivasi kerja berpengaruh positif dan signifikan terhadap kinerja karyawan PT. Hazara Cipta Pesona baik secara parsial, maupun secara simultan.

\section{DAFTAR PUSTAKA}

Adelina, S. R. (2010). Analisis beban kerja mental dengan metode Nasa-TLX. Yogyakarta: Teknik industri, Institusi sains \& Teknologi AKPRIND

Afandi, P. (2018). Manajemen Sumber Daya Manusia (Teori, Konsep dan Indikator). Riau: Zanafa Publishing. 
Anwar, P. M. (2013). Manajemen Sumber Daya Manusia Perusahaan. Bandung: Remaja Rosda Karya.

Bangun, W. (2012). Manajemen Sumber Daya Manusia. Jakarta: Erlangga.

Bejo, S. (2013). Manajemen Tenaga Kerja Indonesia, Pendekatan Administratif dan Operasional. Jakarta: Bumi Aksara.

Edy, S. (2011). Manajemen Sumber Daya Manusia. Jakarta: Kencana. Group.

Hani, H. (2011). Manajemen Personalia dan Sumber Daya Manusia. Yogyakarta: BEFEE.

Hani, H. (2014). Manajemen. Yogyakarta: BPFE Yogyakarta.

Hasibuan, M. S. P. (2006). Manajemen Dasar, Pengertian, dan Masalah. Jakarta: Bumi Aksara.

Hasibuan, M. S. P. (2016). Manajemen Sumber Daya Manusia. Jakarta: Bumi Aksara.

Rivai, V., \& Basri. 2005. Manajemen Sumber Daya Manusia Untuk Perusahaan, Jakarta: Rajagrafindo Persada

Rivai, V. (2011). Manajemen Sumber Daya Manusia untuk Perusahaan: dari Teori ke Praktik, Jakarta: RajaGrafindo Persada.

Robbins, S. P. (2008). Perilaku Organisasi. Jakarta: PTI Indeks.

Sadili, S. (2012). Manajemen Sumber Daya Manusia. Bandung: Pustaka Setia.

Salidi, S. (2010) Manajemen Sumber Daya Manusia. Bandung: Pustaka Setia.

Sanny, L., \& Kristanti, S. (2012). Pengaruh Lingkungan Kerja dan Job Insecurityterhadap Motivasi Kerja dan Dampaknya pada Kinerja Karyawan Outsourcing Mall Lippo Cikarang. Binus Business Review, 61-69.

Sekaran, U. (2006). Metodologi Penelitian Untuk Bisnis. Jakarta: Salemba Empat.

Siagian, S. P. (2012). Manajemen Sumber Daya Manusia. Jakarta: Bumi Aksara.

Sinambela, L. P. (2016). Manajemen Sumber Daya Manusia. Jakarta: Bumi Aksara.

Sugiono, E., \& Pratista, R. M. (2018). Pengaruh Kepemimpinan Transformasional, Motivasi dan Lingkungan Kerja Fisik terhadap Kinerja Karyawan PT. Rafa Topaz Utama. Jurnal Ilmu Manajemen Oikonomia. 14(2): 43-58.

Sugiyono. (2012). Metode Penelitian Kuantitatif, Kualitatif, dan R\&D. Bandung: Alfabeta.

Sugiyono. (2013).Memahami Penelitiian Kualitatif. Bandung: Alfabeta.

Sugiyono. (2013). Metode Penelitian Bisnis. Bandung: Alfabeta.

Sugiyono. (2014). Metode Penelitian Kuantitatif, Kualitatif dan Kombinasi (Mixed Methods). Bandung: Alfabeta.

Sugiyono. 2017. Metode Penelitian Kuantitatif, Kualitatif, dan R\&D. Bandung: Alfabeta.

Sukandarrumidi. (2012). Metodologi Penelitian. Yogyakarta: Gajah Mada University Press.

Susanty, A., \& Baskoro, S. W. (2012). Pengaruh motivasi kerja dan gaya kepemimpinan terhadap disiplin kerja serta dampaknya pada kinerja karyawan (studi kasus pada pt. Pln (persero) apd semarang). J@ Ti Undip: Jurnal Teknik Industri, 7(2), 77-84.

Sutrisno. (2016). Manajemen Sumber Daya Manusia. Jakarta: Kencana Prenada Media.

Veithzal Rivai. 2011. Manajemen Sumber Daya Manusia Untuk Perusahaan Dari Teori Ke Praktek. Jakarta: Raja Grafindo Persada.

Wibowo. (2010). Manajemen Kinerja. Jakarta: Rajawali Press.

Yadi, A (2012). Kesantunan Berbahasa Mandailing dalam Tindak Tutur Direktif Anak Kepada orang Tuanya di Naguri Ujung Gading Kecamatan Lembah Melintang Kabupaten Pasaman. Jurnal Pendidikan Bahasa dan Sastra Indonesia, 1(1), 90-95. 